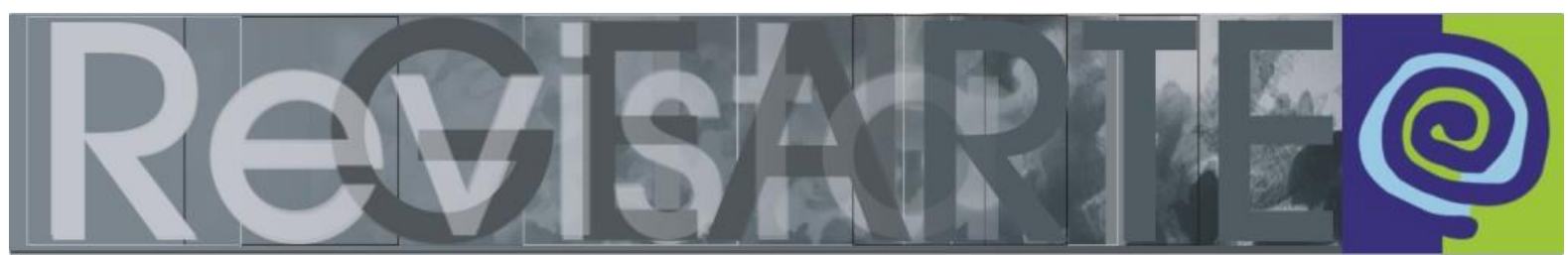

ISSN 2357-9854 | e-ISSN 2596-3198 (online)

\title{
Coração Enjaulado versus Cibervida Artista: um processo de descolonização da alma
}

\author{
Fernanda Pereira da Cunha \\ (Universidade Federal de Goiás - \\ UFG, Goiânia/ GO, Brasil)
}

\begin{abstract}
RESUMO - Coração Enjaulado versus Cibervida Artista: um processo de descolonização da alma - Este ensaio estuda a Pedagogia do Acontecimento ao realizar a tessitura reflexiva com a Abordagem Triangular, buscando enlaçar possíveis axiomas pelos auspícios interterritoriais no locus de proposituras contextuais demarcadas pelo intento pedagógico ao ascender a concepção de que resistir é um ato crítico de se Educar a plenitude de se Aprender... Considera-se essencial a edificação da estética da (re)existência pelo desenvolvimento do pensamento poético divergente em seus valores identitários, ao se analisar acerca da promoção um novo estado ontológico de transbordamento significativo, autogovernativo e identitário, em prol da descolonização da vida servil bem como da invisibilidade do ser e por assim dizer, do desenjaulamento da vida ou melhor, para o não enjaulamento da alma... Cujo transbordamento ciberarte/educativo se engendra no tocante ao desenvolvimento da criticidade à consumação plena da Cibervida Artista.
\end{abstract}

PALAVRAS-CHAVE

Pedagogia do Acontecimento. Abordagem Triangular. Cibervida Artista. Ciberarte/Educação. Descolonização.

ABSTRACT - Caged Heart versus Cyberartist Life: a process of decolonization of the soul This essay studies a Pedagogy of the Event by performing a reflexive tessitura with a Triangular Approach, with the search for an axiom by the interterritorial headphones without locus of contextual purposes demarcated by the pedagogical intent when ascending to a project of resistance to a critical act of itself To educate a fullness of learning... The construction of the aesthetics of (re) existence by the development of divergent poetic thought in its identity values is considered essential, when analyzing about the promotion a new ontological state of meaningful, self-governing and identity overflowing, in favor of the decolonization of the servile life well as of the invisibility of being and, as it were, of the unchaining of life or, rather, of not caging the soul ... Whose cyberart/education overflow is engendered in the development of criticality to the full consummation of the Cyber Life Artist.

KEYWORDS

Pedagogy of the Event. Triangular Approach. Cyberartist Life. Cyberart/Education. Decolonization. 


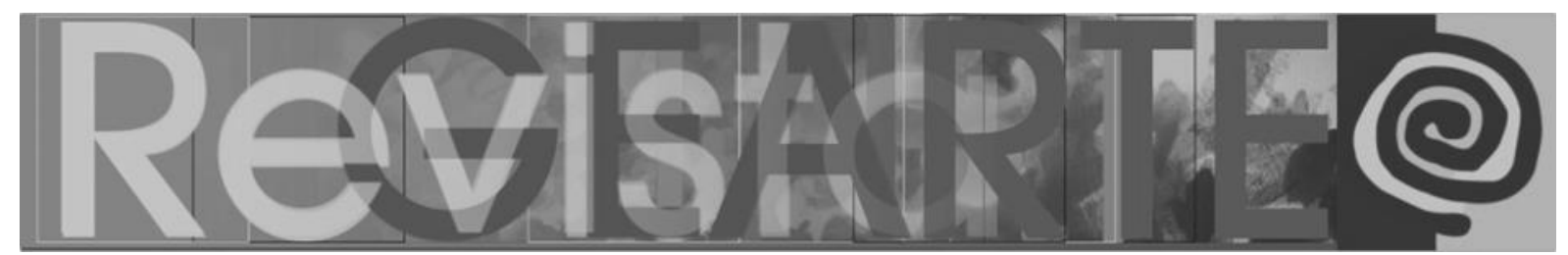

Figura 1 - Caged heart 2

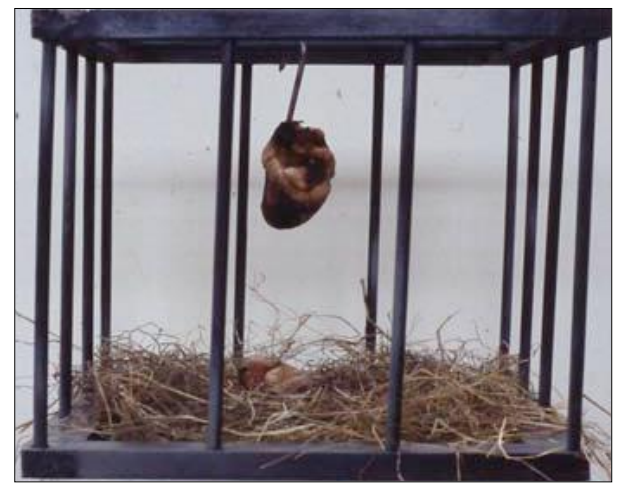

Fonte: Atkinson (2014, p. 4).

Ao se conceber que resistir é um ato crítico de se Educar a plenitude de se Aprender... Conclamo pela imagem acima, intitulada The caged heart, de autor e data não identificados, uma vez que este texto se baliza na acepção de intervenções ciberarte/educativas pelo viés da pedagogia do acontecimento, ao se compreender a relevância da ressignificação da vida pela arte.

Para tanto, considera-se a edificação da estética da (re)existência pelo desenvolvimento do pensamento poético divergente em seus valores identitários, cuja intervenção tem como premissa promover um novo estado ontológico de transbordamento significativo, autogovernativo e identitário, em prol da descolonização da vida servil bem como da invisibilidade do ser e por assim dizer, do desenjaulamento da vida ou melhor, para o não enjaulamento da alma...Vale ressaltar que desenjaular o coração se vincula pois, nesta reflexão, ao processo intrínseco da autogovernabilidade, pela construção crítica da identidade.

Eis que se ascende para este cenário a pedagogia do acontecimento, em que Dennis Atkinson (2014, p. 4), professor emérito da Universidade Goldsmiths de Londres, do Departamento de Estudos Educacionais e do Centro de Artes e Aprendizagem, em um dado contexto específico, conta sobre um fato que presenciou em uma sala de aula entre professor e aluno no ensino médio:

Alguns anos atrás, eu estava entrevistando um professor de escola secundária em sua sala de artes quando uma de suas alunas do último ano entrou e pediu para conversar. Isso aconteceu na época da crise da encefalopatia espongiforme bovina, quando milhares de animais foram 


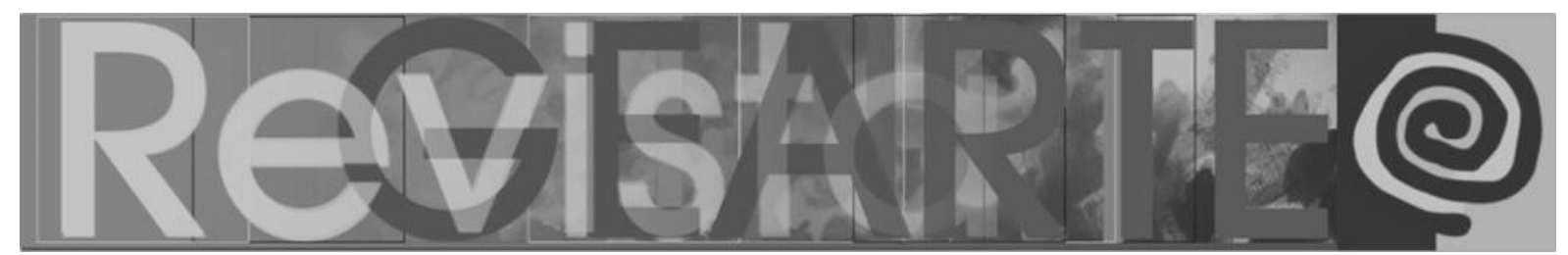

abatidos em todo o país e suas carcaças queimadas em grandes fogueiras. O episódio desencadeou um intenso debate político e ético. A aluna carregava uma gaiola feita de ripas de madeira. Disse que não a havia feito, mas que queria usá-la para sua peça avaliativa que seria colocada em exposição na semana seguinte. Ela pretendia pendurar o coração congelado de uma vaca dentro da gaiola. O fundo seria coberto com palha e um mapa da Inglaterra. Então perguntou ao professor se haveria algum problema e se ele achava que ela tinha condições de passar no exame. O professor e eu apenas nos entreolhamos. (Tradução nossa).

O fato relatado por Atkinson ressalta a importância de se experienciar o real no processo de ensino-aprendizagem, como uma maneira de quebrar fronteiras pela perfuração das formas simbólicas. Assim, o real vem a ser contextualizado pelo educando no processo de desenvolvimento da singularidade do eu em seu processo existencial-ontológico (ver Figura 2).

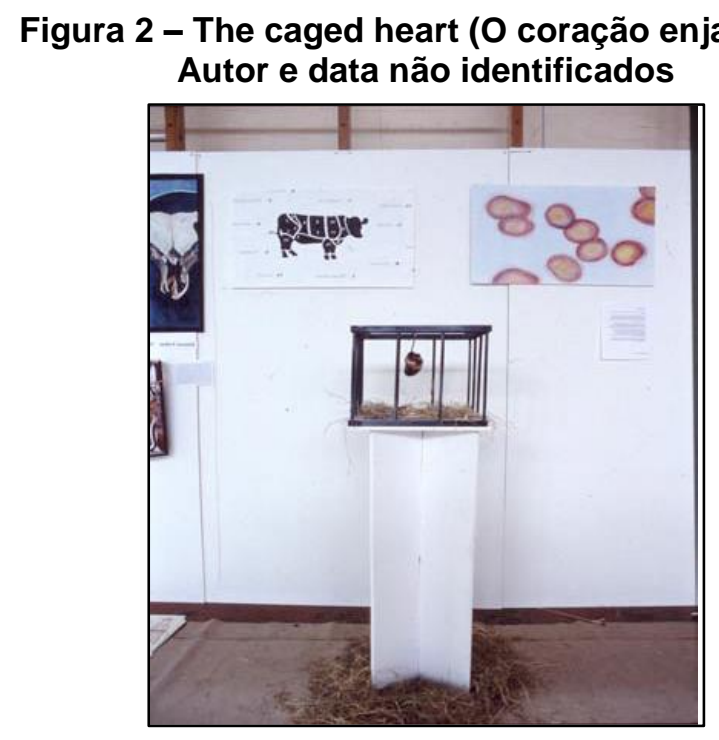

Fonte: Atkinson, 2014, p. 4.

Note-se que não se trata de se inserir um determinado dado - ainda que real no processo de ensino- aprendizagem, mas o acontecimento ser o ato pedagógico em si:

O real sugere lacunas no simbólico, bem como momentos em que nossas formas simbólicas se rompem, em que a ordem simbólica é perfurada, uma fragmentação de fronteiras em que nossas práticas de representação são severamente perturbadas por algum acontecimento. Se aliarmos essa ideia do real a um ato de aprendizagem rumo à concretização da verdadeira aprendizagem, tal combinação expõe uma situação de risco em que as fronteiras ontológicas se tornam incertas ou rachadas. É quase como se, através desse ato, o eu fosse apagado ante o risco de mudança, segundo um 


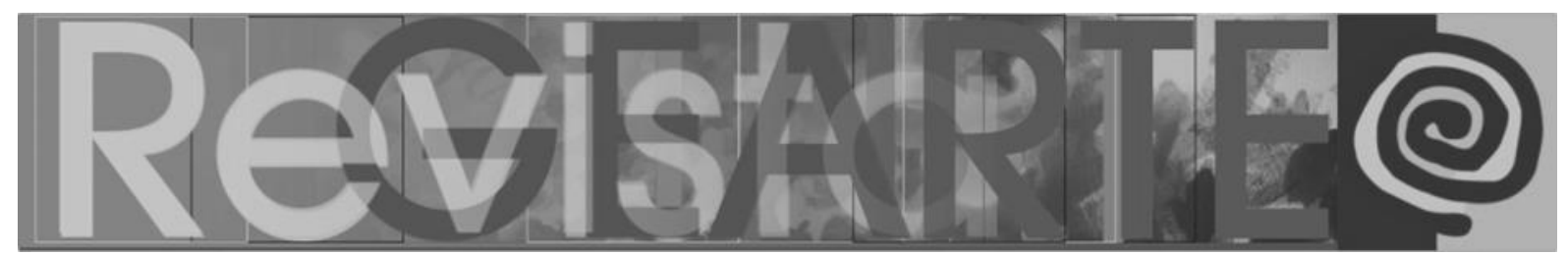

novo conjunto de coordenadas ontológicas. (ATKINSON, 2014, p. 4, tradução nossa).

Trata-se de ações pedagógicas contrárias à invisibilidade daqueles que são marginalizados pelos modos dominantes de compreensão e valor, os quais, na teoria cultural, concernem ao "Outro" que se encontra neste estado.

\section{Aquilo-que-ainda-não-é}

A pedagogia do acontecimento, como enaltece Dennis Atkinson, pode "precipitar um processo ontológico relacional". Sob o conceito That-which-is-not-yet (aquilo-que-ainda-não-é), extraído do livro sobre ética de Badiou (2001), Atkinson (2014, p. 6) teoriza o espaço pedagógico em dois níveis: em seu potencial múltiplo e sobre a ideia de invisibilidade. Vejamos em suas palavras:

Podemos pensar em 'aquilo-que-ainda-não-é' como algo referente a formas de ser que não têm existência, ou seja, que não contam ou que ainda não são valorizadas. Pode abranger estados emergentes de um vir-a-ser, mas também as formas de ser que estão muitas vezes presentes mas ausentes, isto é, que não existem na medida em que se encontram fora ou à margem dos modos dominantes de compreensão e valor. Na teoria cultural, o termo 'outro' é por vezes empregado para designar tal condição.

Nos contextos de ensino-aprendizagem, é bem possível que haja aprendizes cujo status ontológico não seja reconhecido - por isso, seu potencial para o vir-a-ser é limitado - e que, portanto, têm uma existência marginalizada no espaço pedagógico. (Tradução nossa).

Continua Atkinson (2014, p.7) ao exemplificar o potencial múltiplo:

É possível vislumbrar essa situação, por exemplo, quando crianças/estudantes produzem algo misterioso ou incompreensível segundo a perspectiva do referencial pedagógico formado pelos discursos e práticas curriculares que embasam a prática do professor. Pode-se também constatála quando aprendizes de outras culturas se inserem em um contexto pedagógico que não apoia sua existência ou conquistas prévias como aprendizes. Portanto, essa ideia de aquilo-que-ainda-não-é pode ser empregada inicialmente. (Tradução nossa).

Sob o conceito de aquilo-que-ainda-não-é, Atkinson aborda sobre a ideia de invisibilidade ao considerar políticas de existência estabelecidas nos ambientes pedagógicos, especialmente àqueles marginalizados e/ou oprimidos, exemplifica Atkinson: 


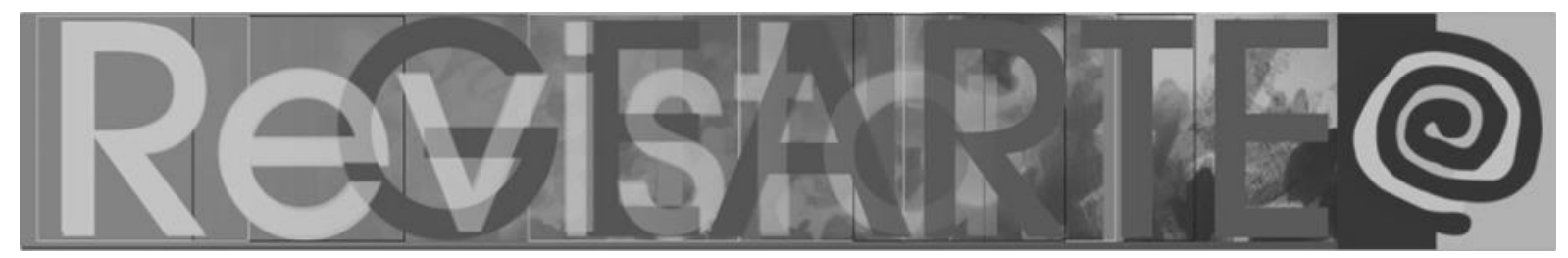

Por exemplo, graças aos estudos de Bourdieu, Bernstein e outros, e de seus conceitos teóricos de capital cultural e violência simbólica, sabemos que o conteúdo curricular do espaço pedagógico pode ser culturalmente enviesado de modo a privilegiar os aprendizes que têm acesso às formas valorizadas de conhecimento (capital cultural). Assim, os que não têm esse acesso podem ser vistos como aquilo-que-ainda-não-é no contexto pedagógico da educação pública e, infelizmente, permanecer nesse vácuo ontológico. (ATKINSON, 2014, p. 7, tradução nossa).

Não é raro, diria mesmo ser corriqueiro, encontrarmos ações pedagógicas excludentes à cultura digital juvenil, visto que há professores e professoras que, seguros de seus discursos e práticas do currículo escolar, se manifestam considerando ser incompreensíveis e misteriosas as ciberexpressões das cibervidas de nossos alunos e alunas, não suportando suas ciber[re]existências e conquistas em seus contextos culturais. Entretanto, Atkinson adverte quanto à relevância de se desdobrar aprendizagem como movimento para um novo estado ontológico com vistas a se aceitar novos estados de existências como aprendizes, ampliando, assim, a potencialidade pedagógica:

[...] onde a aprendizagem abre novas possibilidades, novas formas de ver as coisas, novas formas de dar sentido ao que nos é apresentado em nossos diferentes modos de existência, então esse movimento envolve "aquilo-queainda-não-é". Aceitar esses novos estados implica aceitar novos estados de existência como aprendizes. Tal ideia apontaria para um espaço de potencial infinito. De que forma podemos promover e apoiar esse espaço? (ATKINSON, 2014, p. 7, tradução nossa).

Reitero, contextualizando, a questão de Atkinson pela cibercultura: de que maneira promover ações ciberarte/educativas como movimento para um novo estado ontológico em prol de ressignificações ciberexistenciais valendo-se da vida artista de nossos alunos e alunas? Ou seja, como descolonizar, democratizando a arte balizando-nos na produção do pensamento divergente, manifesta pela poiesis estética na solução de problemas em prol da visibilidade do ser com autonomia que pulsa em estados de liberdade, ou seja, para fora da gaiola? 


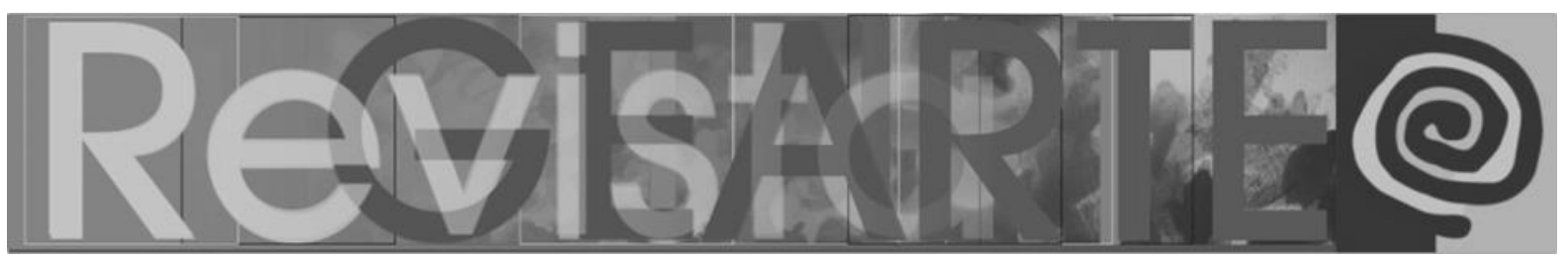

Pedagogia do Acontecimento: uma proposição axiomática dialógica com a Abordagem Triangular

A pedagogia do acontecimento ou pedagogia contra o Estado, ou ainda pedagogia do não conhecido, como recomenda Dennis Atkinson, evoca a necessidade de se refletir sobre o trabalho anterior e posterior de Foucault. Com relação ao trabalho anterior de Foucault, consideram-se os processos de vigilância, regulação, disciplinaridade e normalização que direcionam a conduta dos professores à formação dos estudantes, em que ambos os sujeitos são formados, regulados e normatizados:

\begin{abstract}
É nesses processos de regulação e normalização que, segundo Butler, "a viabilidade do sujeito, seus parâmetros ontológicos e epistemológicos" se estabelecem. Portanto, ser uma "boa mãe" ou uma "criança inteligente", de acordo com Walkerdine (1990, p. 199), "faz sentido apenas conforme os termos estipulados pelo bem-estar social, pelos discursos e práticas pedagógicas, médicas e jurídicas. Tais discursos e práticas observam, sancionam e corrigem o modo como agimos; eles buscam definir quem e o que somos". (ATKINSON, 2014, p. 1, tradução nossa).
\end{abstract}

Desse modo, as questões de ética, no tocante aos processos de aprendizagem no viés das ações pedagógicas, costumam girar em torno da norma estabelecida como a imposição de um currículo nacional às/nas escolas -, segregando a relevância dos contextos socioculturais, bem como suas particularidades que podem promover mudanças nas realidades vividas. Nesse contexto, Atkinson (2014, p. 1, tradução nossa) adverte para a produção de uma espécie de violência sobre a diferença, ao explicar que tal situação se "constitui, com efeito, um dispositivo reacionário que tentava lidar com um mundo em rápida transformação".

O trabalho posterior de Foucault traz um salto de efeito do discurso para centrar na formação do "eu", que ao incluir a pessoa insere-a como um ser humano em relação e por intermédio das normas, cujo processo se integra à crítica pelo ato poiético, criativo e estético. Abre, dessa forma, a possibilidade de se viabilizar o questionamento aos processos pedagógicos até então utilizados, podendo introduzir, assim, o intento e sua prática pedagógica crítica, incitando à questão da ética na inclusão do eu neste processo: 


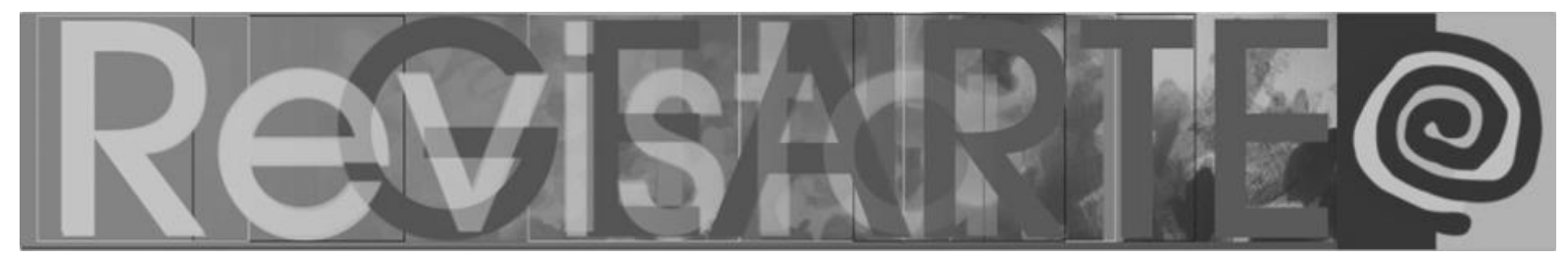

Essa posição crítica em relação aos referenciais normalizadores constitui uma base sobre a qual podemos começar a questionar os parâmetros de ensino-aprendizagem, sob os quais os sujeitos pedagogizados são produzidos. Tal prática crítica introduz a questão da ética na medida em que a crítica aos referenciais normalizadores é, de maneira implícita, uma crítica ao eu, sendo este organizado/reconhecido e constituído no âmbito de tais referenciais. (ATKINSON, 2014, p. 2, tradução nossa).

Nesse contexto, estabelece-se o conflito da posição crítica fomentadora de questionamentos sobre as normas reguladoras de condutas e procedimentos, uma vez que estes se submetem à padronização, cujas diretrizes estruturantes convergem aos auspícios trazidos por Foucault em seu trabalho anterior. Assim, pode-se inserir o risco pedagógico no processo de ensino-aprendizagem na instância entre os então pseudoalicerces dos parâmetros curriculares com a prática pedagógica pelos ditames que se engendram pela ética no tocante à postura crítica educativa. Isso porque, segundo explica Atkinson (2014, p. 2), "não é incomum ter experiências que não podem ser entendidas sob referenciais estabelecidos, quando pressupomos uma base comum que não é, de fato, segura". Tal fato pode ser um indicativo de tensão entre representação e ação propriamente dita no processo de ensino-aprendizagem, conforme nos esclarece o autor:

\begin{abstract}
Se, numa relação pedagógica, fantasia-se sobre o aprendiz por meio da norma, o Outro da norma, então este passa a ser uma identidade substituta (ela produz aquilo que o professor espera). Se o encontro pedagógico começa com a pergunta "Quem é você?", então uma relação diferente parece vir à tona e torna-se possível transformar essa pergunta em "De que forma o outro aprende?". (ATKINSON, 2014, p. 3, tradução nossa).
\end{abstract}

Swift e Steers (1999) salientam que a noção de tomada de riscos tem sido aos educadores objeto de se promover abordagens criativas e individuais à aprendizagem, dada a necessidade de ações pedagógicas flexíveis que atendam aos resultados inesperados que podem estar presentes no percurso do processo pedagógico da edificação do eu. Vale ressaltar que a terminologia "eu" foi inicialmente utilizada por psicanalistas ingleses, como Donald Woods Winnicott (1896-1971), indicando a pessoa como lugar de atividade psíquica. Assim, o eu vem a ser o produto de processos dinâmicos que asseveram a unidade e a totalidade do sujeito. Ou seja, o eu define a pessoa na sua individualidade e subjetividade. 


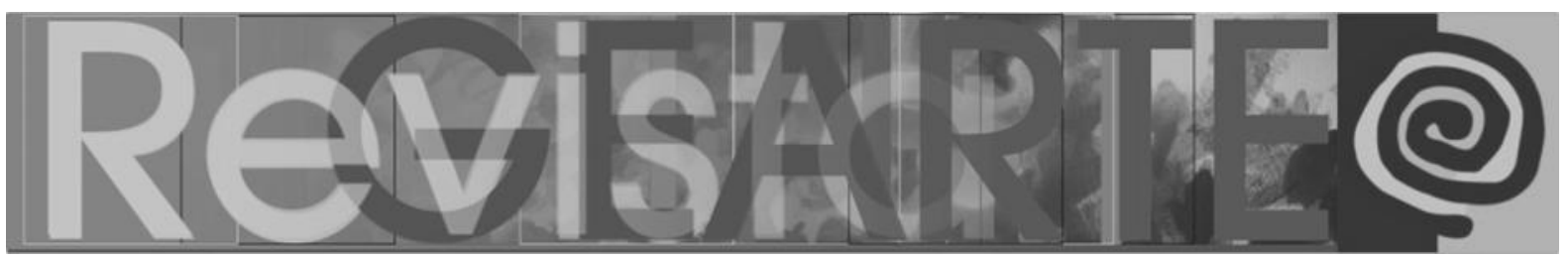

A relevância deste fato, para este estudo, é a pertinência que se tem acerca da sua válvula de escape no descontrole daqueles processos de ensino-aprendizagem guiados por resultados específicos. Refiro-me a abordagens contextuais, especificamente a Pedagogia do Acontecimento de Dennis Atkinson sendo dinamizada pelo eixo questionador de três ações mentais concomitantes em prol do desenvolvimento da cognição perceptiva propostos pela Abordagem Triangular criada e sistematizada pela professora Ana Mae Barbosa, que se inserem pela noção de que os professores permeiam nos riscos que correm e os agudizam ao incentivar seus alunos e alunas a também assumirem riscos em seus contextos específicos de aprendizagem. São riscos peculiares do princípio da natureza do acontecimento, uma vez que o âmago deste se estabelece no deixar as coisas acontecerem sem uma consciência exata do resultado e cujo resultado dessa ação conduz a ressignificações singulares pela vivência à edificação do eu, num processo particular balizado na pesquisa.

Nesse sentido há um transbordamento em relação aos parâmetros formais de ensino, uma vez que os conteúdos a serem abordados podem estar vinculados ao contexto-vida do educando. O contexto sendo o amálgama de um espectro e/ou aspecto da vida do educando pode promover a criticidade autônoma da estética de sua vida, viabilizando ressignificações da paisagem interna que compõe esse universo sígnico e, por assim dizer, a matéria-prima da expressividade - crítica. O eu, no tocante ao seu caráter identitário, converge para a bandeira de um indivíduo.

Se o plano de ensino transbordar pelas vias de estratégias arte-educativas impulsionadas por questionamentos motrizes oriundos do intento pedagógico do ato docente crítico, questionamentos esses voltados para a ascensão do desejo indócil e curioso do estudante à investigação, o risco pedagógico é aqui absorvido pelo (im)pulso ideológico em duas vias concomitantes: de se ensinar e se aprender, na promoção do percurso cartográfico de caráter identitário à formação plena do ser humano. Eis que se instaura a bandeira no acontecimento pelo acontecimento: o meta-acontecimento. 


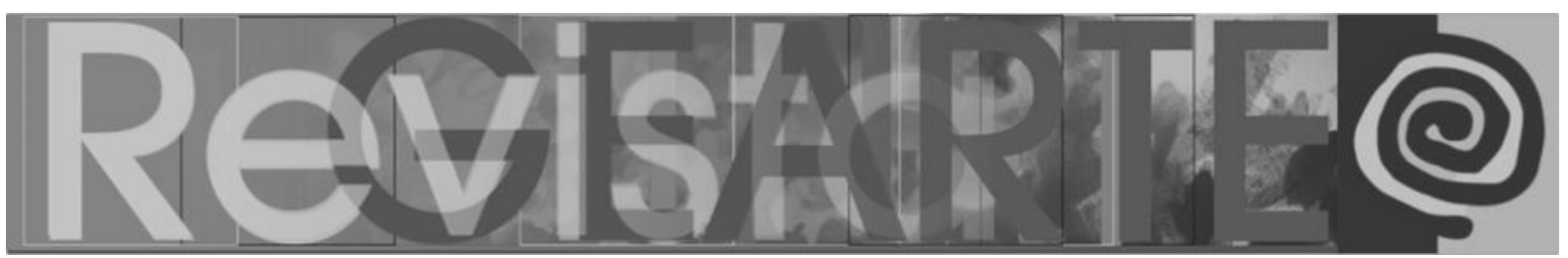

Neste paradigma estabelecer-se-á um processo amalgamo entre a Pedagogia do Acontecimento com a Abordagem Triangular pela instância axiomática dialógica dada a natureza do intento educativo estar concentrado no contexto do acontecimento real pulsante da vida enquanto acontecimento pedagógico, cujo acontecimento se pedagogiza pela abordagem arte/educadora consciente, integradora e pluralista de concepção pilar no processo de ensino/aprendizagem acionado por três ações mentais concomitantes (informação, decodificação e produção) essenciais na elaboração/produção de solução de problemas em prol do desenvolvimento cognitivo perceptivo crítico num dado acontecimento da vida. Assim, a Pedagogia do Acontecimento e Abordagem Triangular retroalimentam 0 processo de desenvolvimento da singularidade do eu em seu processo existencial-ontológico.

\section{Abordagem Triangular: acontecimento político-educativo em diálogo com o tempo}

Será a partir da situação presente, existencial, concreta, refletindo o conjunto de aspirações do povo, que poderemos organizar o conteúdo programático da educação ou da ação política. (FREIRE, 1987, p. 86).

Ao se inserir o caráter educativo pela Pedagogia do Acontecimento pela via da Abordagem Triangular, os riscos são absorvidos pelos (im)pulsos da ideologia pedagógica docente, que está comprometida com o desenvolvimento da consciência crítica e, por assim dizer, com a formação plena da pessoa em diálogo com o tempo.

A Abordagem Triangular é uma abordagem em processo, em diálogo com o tempo, portanto, contínua, dado seu aspecto orgânico, por ser uma perspectiva cuja gênese epistemológica se alicerça em seu caráter genuinamente contextual, para o desenvolvimento da identidade cultural e da cognição/percepção.

Assim, a sistematização da Abordagem Triangular acontece no tempo gramatical do gerúndio, porque dialoga no curso do e com o tempo. Neste sentido, a força motriz desta Abordagem, de natureza conceitual cultural e dialogal, torna-a flexível e contemporânea no curso do tempo. A Abordagem Triangular perfaz uma rede sistêmica, por isto, viva, orgânica e, portanto, pulsante no e com o curso dos acontecimentos vida. Compreender o processo de edificação desta Abordagem está, 


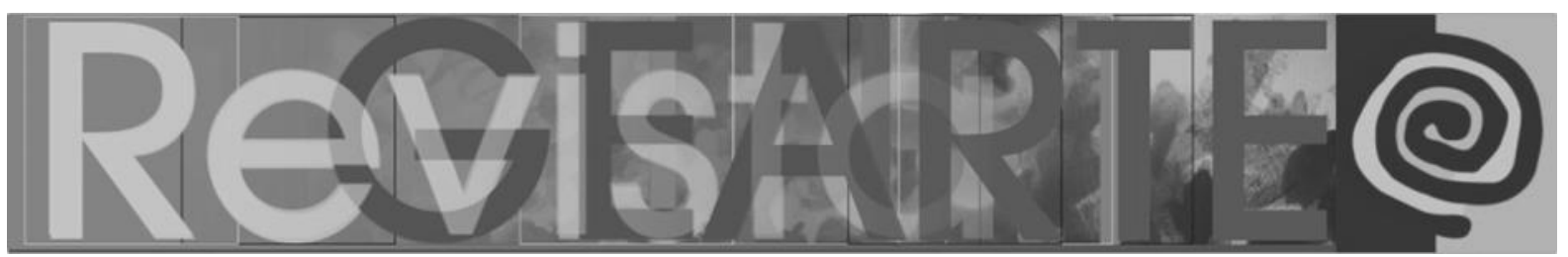

portanto, intimamente vinculado à trajetória epistemologicamente teórica/empírica que a professora Ana Mae Barbosa constitui em sua vida com a arte e seu ensino.

$\mathrm{Na}$ busca determinada de uma abordagem arte/educativa pós-colonialista, a professora Ana Mae Barbosa, conectada com as vozes do mundo, pela sua natureza indócil, crítica, de educadora, sempre cultivou a pesquisa como meio de reflexão para sua análise, a qual mantém diálogo investigativo com abordagens educativas do ensino das artes no cenário internacional. É neste ambiente investigativo, de olhar brasileiro em relação internacional, que se situa a Abordagem Triangular póscolonialista - e por assim dizer descolonizadora -, a qual é um ícone arte/educativo na contemporaneidade.

Assim, a Abordagem Triangular, criada na trajetória epistemológica traçada pela professora Ana Mae Barbosa, em diálogo "com o discurso pós-moderno global e o processo consciente da diferença cultural entre as nações" (BARBOSA, 1998, p. 33), interage em seu âmbito conceitual com outras três abordagens sistematizantes do ensino de artes: as "Escuelas al Aire Libre" mexicanas, o Critical Studies inglês e o $\mathrm{DBAE}^{1}$ americano, bem como com abordagens que podem se completar e/ou se conectar pelo viés do acontecimento, em que estejam engajadas em proposições nãolineares - ou seja, não-disciplinares, privilegiando os aspectos contextuais sígnicos da pessoa, promovendo o desenvolvimento da consciência crítica em prol da formação ontológica - identitária e por assim dizer pela formação do pensamento autônomo capaz de (re)criar-se à necessária consumação estética da vida na edificação do eu e vice-versa.

Estas abordagens contribuem para o fortalecimento das acepções sobre a mediação da arte e seu ensino traçadas por Barbosa na Abordagem Triangular, em

1 Vale salientar que a Abordagem Triangular converge com o DBAE no tocante aos seus aspectos conceituais, mas não em seus aspectos estruturais, uma vez que conceitualmente o DBAE se apresenta como um sistema para o ensino da arte de ideias pós-modernas, mas estruturalmente propõe um procedimento linear de conhecimento, Ana Mae Babosa se opõe "porque esta disciplinariza os componentes da aprendizagem da arte, separando-os em fazer artístico, crítica de arte, estética e história da arte", assumindo seu caráter construtivo modernista (BARBOSA, 1998, p. 37). 


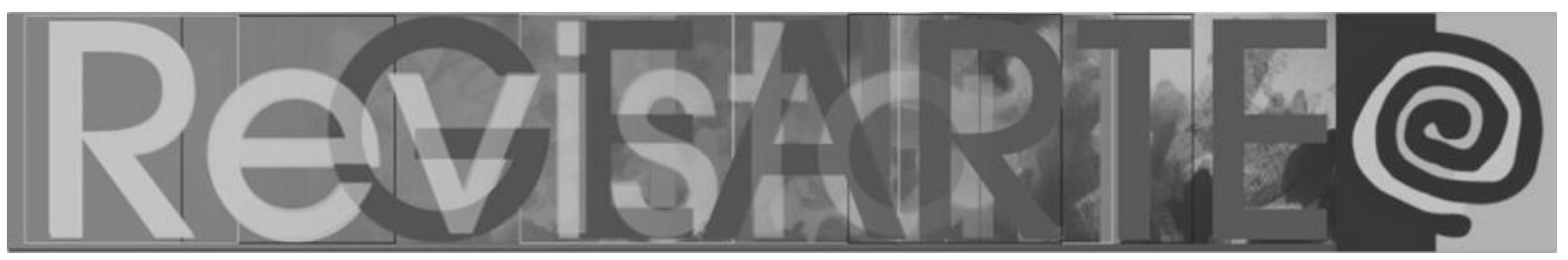

virtude dos aspectos convergentes e divergentes presentes em suas sistematizações educacionais.

Neste paradigma entre história de vida e edificação de uma trajetória pedagógica se torna latente suas relações contextuais de pertencimento e produção histórico-cultural oriunda dos acontecimentos pedagógicos em seus processos no tocante à relação intrínseca entre a ação política e a ação educativa.

Ao se considerar as relações contextuais de pertencimento e produção histórico-cultural das pessoas, os acontecimentos pedagógicos (ou a pedagogia do acontecimento) são processos político-educativos e/ou processos educativo-políticos, uma vez que é impossível manifestar uma educação neutra. Paulo Freire (2003, p. 23-24) assim esclarece:

[...] no caso do processo educativo quanto no do ato político, [em que] uma das questões fundamentais seja a clareza em torno de a favor de quem e do quê, portanto contra quem e contra o quê, desenvolvemos a atividade política. Quanto mais ganhamos esta clareza através da prática, tanto mais percebemos a impossibilidade de separar o inseparável: a educação da política. Entendemos então, facilmente, não ser possível pensar, sequer, a educação, sem que se esteja atento à questão do poder.

Com base nesse paradigma, as ações arte-educativas se apresentam intrínsecas a expressões pedagógicas oriundas de acontecimentos peculiares, em cujos processos são produzidos símbolos que edificam cada bandeira docente, com sua singularidade identitária própria, representando a cartografia ideológica educativa num dado contexto sociocultural. Sendo assim, mediar os riscos do processo de ensino-aprendizagem pode favorecer o encorajamento do aprender, do redescobrir, do recriar, do ressignificar o ser e o estar do educando e da educanda no e com o mundo em que se encontram inseridos.

O acontecimento político-educativo se fundamenta na ética da pedagogia discutida, com vistas a descortinar o lócus significativo/significante de nossos alunos pelos procedimentos verdadeiros de aprendizagem. Vale ressaltar que a terminologia verdade está aqui engajada nas proposições do professor Dennis Atkinson (2014, p. 3, tradução nossa), ao salientar que está mais preocupado "em abrir espaços 


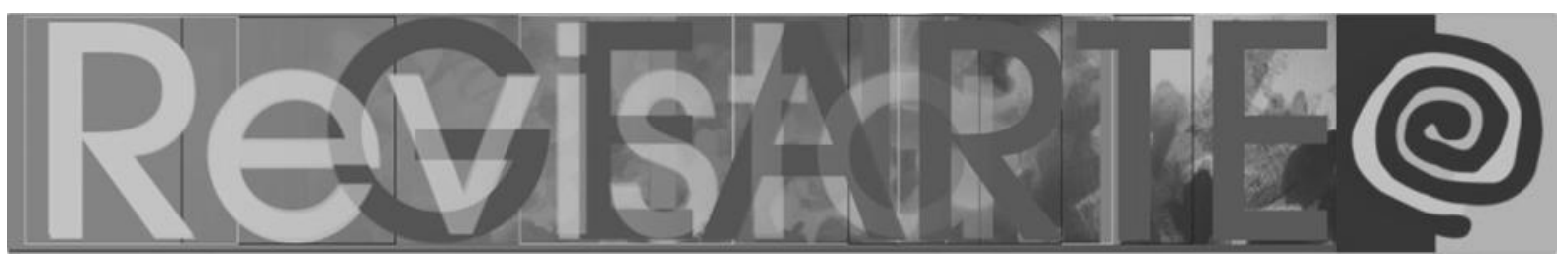

pedagógicos à verdade dos encontros e eventos de aprendizagem que em analisar os sujeitos (normativos) do conhecimento". Apoiado em Alain Badiou, segundo Atkinson (2014, p. 5, tradução nossa), "a verdade do ato de ser surge de um acontecimento por meio do qual aparece um sujeito (nesse caso, um aprendiz)".

Assim, ao interpretar Badiou, Atkinson conceitua verdade ligando-a à erupção de um acontecimento e suas consequências genéricas, não tendo nada a ver com conhecimento ou significado, uma vez que a verdade não é o que o conhecimento produz; pelo contrário, "é o que excede, em determinada situação, o conhecimento que a explica" (LECERCLE, 1999, p. 8 apud ATKINSON, 2014, p. 5, tradução nossa). Em outras palavras, "a verdade é aquilo que não pode ser concebido em determinada situação segundo o conhecimento existente, 'uma verdade é uma perfuração de tal conhecimento"' (ATKINSON, 2014, p. 5, tradução nossa). Assinala Atkinson (2014, p. 5 , tradução nossa) que é possível "compreender essa ideia de verdade como algo além do significado ou como um vazio no significado corrente". Nesse sentido, Atkinson (2014, p. 5, tradução nossa) realça a relação que Badiou (2005) observa à educação: "a educação (à exceção de suas manifestações opressivas ou perversas) nunca significou nada além do seguinte: organizar as formas do conhecimento de tal modo que alguma verdade venha a perfurá-las". A professora Ana Mae Barbosa, ao informar sobre o I Congresso Internacional de Educação Artística e Cultura Visual, com o tema "Hacia una educación inclusiva e interrelacional", que ocorreu em Lima, no Peru, em fevereiro de 2015, destaca que a pedagogia do acontecimento é baseada em Badiou:

Badiou é marxista, defende a ideia de uma internacionalização positiva da revolta. Sua filosofia é polifônica, contra sistemas fechados, defendendo um sistema humanizado exigente que inclui as teorias matemáticas modernas e quatro dimensões da existência: o amor, a arte, a política e a ciência. Badiou definiu os processos políticos atuais como uma "guerra das democracias contra os pobres". O filósofo é um teórico dos processos de ruptura e não um mero panfletário?

2 Disponível em: http://www3.eca.usp.br/sites/default/files/form/biblioteca/acervo/producaoacademica/002735784.pdf. Acesso em: 10 maio 2018. 


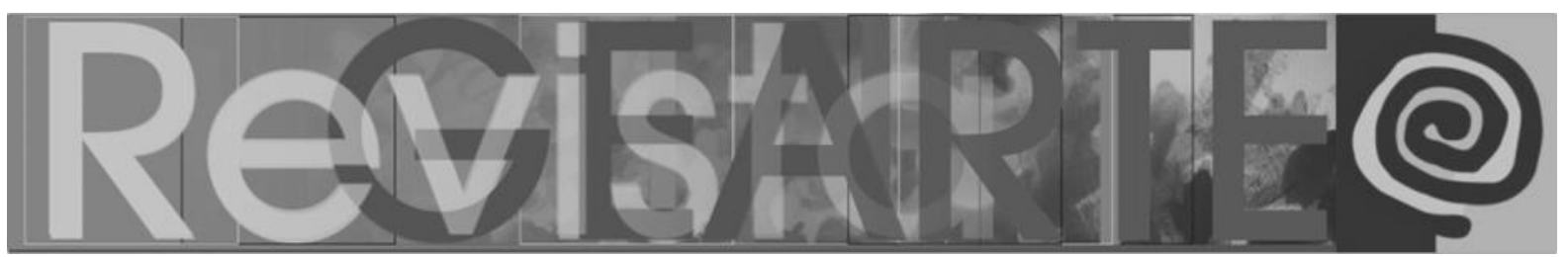

Neste sistema humanizado em que se exige a inclusão da existência pelas dimensões do amor, da arte, da política e da ciência, a verdade está inserida como caráter educativo, no transbordamento significativo de um processo de vivência singular oriunda da consumação estética, como nos adverte John Dewey (2010). Consumação que se enlaça pelo/no acontecimento da experiência significativa, em que a qualidade da experiência estética está vinculada à singularidade do acontecimento, necessitando de comprometimento à entrega plena num dado fato que demarca o real. Por isso o acontecimento político-educativo é concebido num processo identitário: existencialmente crítico.

\title{
Cibervida artista: uma proposição de autoaprendizagem demarcada pelo acontecimento crítico viral conduzido pela resistência descolonizadora do pensamento divergente
}

\begin{abstract}
Sendo os homens seres em 'situação', se encontram enraizados em condições tempo-espaciais que os marcam e a que eles igualmente marcam. Sua tendência é refletir sobre sua própria situacionalidade, na medida em que, desafiados por ela, agem sobre ela. Esta reflexão implica, por isso mesmo, algo mais que estar em situacionalidade, que é a sua posição fundamental. Os homens são porque estão em situação. E serão tanto mais quanto não só pensam criticamente sobre sua forma de estar, mas criticamente atuem sobre a situação em que estão.

Esta reflexão sobre a situacionalidade é um pensar a própria condição de existir. Um pensar crítico através do qual os homens se descobrem em 'situação' (FREIRE, 1987, p. 101-102).
\end{abstract}

No ensejo existencialista e diria mesmo intrinsecamente descolonizador desta epígrafe em que Paulo Freire adverte sobre os homens serem seres em situação, a premissa é a tendência humana de refletir sobre sua própria situacionalidade, pois sendo por ela desafiado, o ser humano age sobre ela. Assim, a qualidade estética da situacionalidade dos homens converge na medida de suas ações críticas sobre si. Nesse viés, os homens serão tanto mais quanto seus pensamentos críticos agirem sobre sua situacionalidade, promovendo o desenvolvimento amalgamado do pensamento crítico à ação sobre sua própria situacionalidade. E então emerge a 


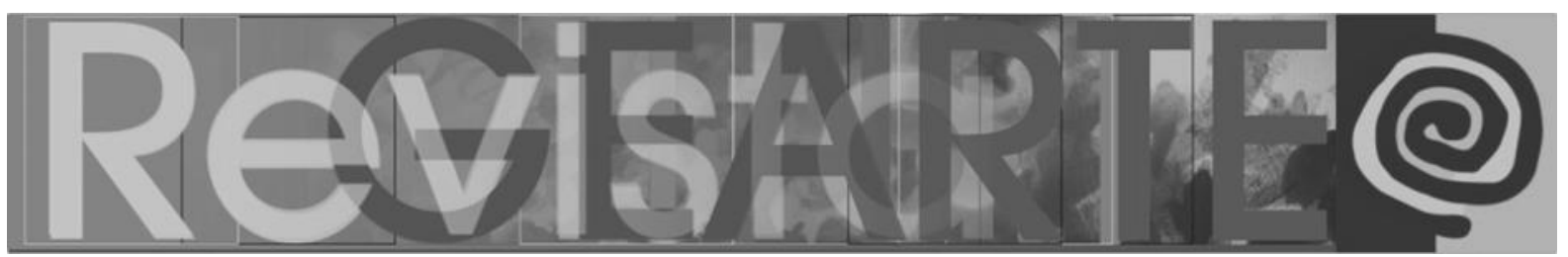

questão: como se apresenta o pensamento crítico sobre a qualidade estética da situacionalidade viral $^{3}$ no tocante às expressões na cibercontemporaneidade?

Há de se considerar a relação intrínseca da qualidade estética da experiência significativa no processo criador, cujo valor sígnico interfere na estética da vida pelo seu processo pessoal na experiência. $\mathrm{Na}$ experiência singular. $\mathrm{Na}$ edificação da identidade. Essas são palavras do filósofo arteducador ${ }^{4}$ Fernando Antônio Gonçalves de Azevedo, que cuidadosamente faz uma pertinente análise reflexiva sobre os conceitos de Vida Artista de Michel Foucault, sob o prisma do filósofo brasileiro Guilherme Castelo Branco, ao inserir tal proposição filosófica à Arteducação. É o que podemos conferir em seu texto Viver a vida como uma obra de arte: por uma arte/educação que diz sim às diferenças (2017).

Fernando Azevedo traz a essência da Vida Artista fundamentado por Foucault, que questiona o fato de a obra de arte estar relacionada exclusivamente aos objetos e nunca à vida das pessoas. Nas palavras de Foucault (1994, p. 617 apud AZEVEDO, 2017, p.129): "Mas a vida de todo indivíduo não é uma obra de arte? Por que uma mesa ou uma casa são objetos de arte, mas não as nossas vidas?"

Por conseguinte, sob os auspícios dos Estudos Culturais, à luz de Tomaz Tadeu da Silva (2007), Azevedo (2017, p. 122) insere a diferença, para a democratização da arte como um saber, ao argumentar que "a Arte (e suas linguagens) é importante na formação do pedagogo por ser o lugar em que a dimensão da imaginação poética é profundamente valorizada". Assim nos fala (AZEVEDO, 2017, p. 122):

O foco de discussão é, pois, a democratização da Arte como um saber, que produz o pensamento divergente, ou seja, possibilita o ser humano ir além

3 Importante assinalar que o termo viral é utilizado para os conteúdos que são intensamente divulgados na internet, ocasionando massiva repercussão na web, ainda que de modo inesperado.

4 Arteducação - terminologia empregada por Fernando Azevedo para significar a instância da fusão entre Arte e Educação, sendo concebida epistemologicamente numa unidade indissolúvel. Assim como Arte e Educação, Arte-Educação, Arte/Educação se caracterizam e são utilizados em empregos específicos, Arteducação também o é. 


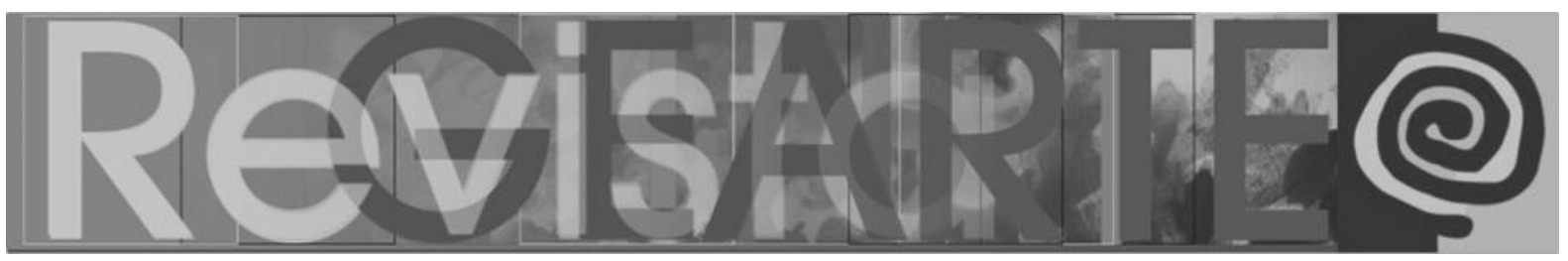

dos padrões estabelecidos pelos poderes, pois a Arte cria as condições de pensar e resolver problemas com imaginação poética.

No âmbito da Vida Artista, as expressões da vida (que diferem das expressões pela vida) - ou ainda a vidaexpressão - inserem-se nas manifestações cartográficas que registram a identidade da subjetividade do real, edificando-se no complexo processo estético-relacional pungente interrelacional entre resistência(s), resiliência(s), (re)existência(s) na imersão do acontecimento. A ação de (re)criar a vida é arte.

Neste contexto, a produção da aluna ${ }^{5}$ intitulada The caged heart, que em português se traduz $O$ coração enjaulado, como disposto acima, em que Dennis Atkinson relata o momento que conferiu uma conversa entre uma estudante e o seu professor do ensino médio, manifesta a elaboração de uma produção estética com a participação desta numa exposição escolar, coloca em evidência empírica uma proposição arte/educativa em prol do desenvolvimento da mente crítica pelo acontecimento para o desenvolvimento da capacidade expressiva autogovernativa, em que se configura um processo de ensino-aprendizagem pelo meta-acontecimento.

Há o contraponto na imagem do coração enjaulado que me leva à reflexão de tantos outros corações enjaulados, dada a situasionalidade acrítica em seus processos existenciais, ontológicos. Há que considerar a exclusão à e/ou na educação. Atkinson adverte neste contexto pela voz da "aquilo-que-ainda não-é".

Ao se valer da educação como prática da liberdade, como recomenda Paulo Freire (2005) em que o desenvolvimento da capacidade crítica somente estabelece pela/na educação, ao se excluir o desenvolvimento da consciência crítica, se aprisiona os desejos próprios, castra a expressão pessoal, amputa a identidade, transplanta em si a voz do "Outro".

5 O nome da aluna que realizou a produção The caged heart não está identificado no texto de Dennis Atkinson. 


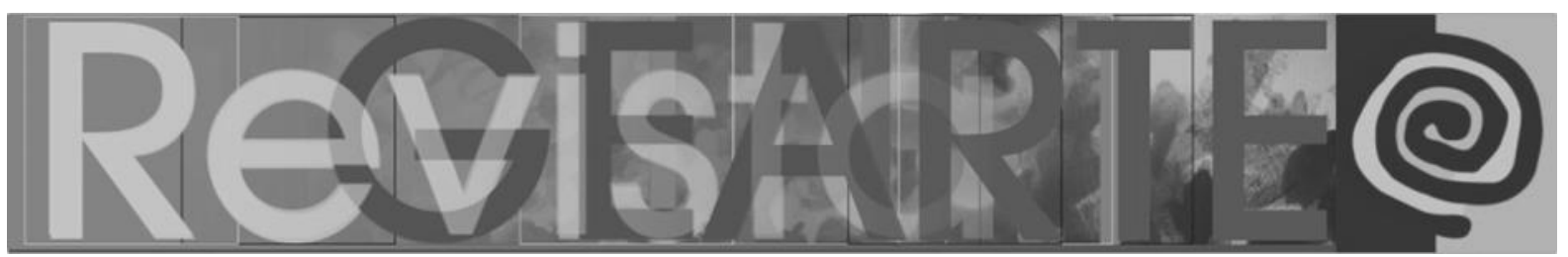

Mas, e quando, a voz enjaulada (re)clama pelo grito, cujo grito é demarcado pela qualidade estética de ecos de natureza do universo ciber? Quando a resistência à opressão colonizadora é demarcada pela autoaprendizagem crítica viral? E quando pulsa liberdade no processo viral?

Neste âmbito, este texto abarca reflexões sobre a cibervida artista advindas de manifestações no/pelo universo digital no âmbito de questões delineadas pela pedagogia do acontecimento viral conduzidas pela diferença, no que diz respeito à edificação do pensamento divergente, propõe o desenvolvimento do pensamento e resolução de problemas com imaginação poética, no campo entre o que a realidade e a Cibervida podem criar.

Quem poderia contrariar-me se disser que, havendo diferença - pensamento divergente, seja de qual natureza for - estabelecer-se-á potencial para palcos oriundos de conflitos sociais de enunciações à resistência... À resiliência... À (re)existência... Para se (re)existir há de se (re)encontrar-se na própria existência, o que vou denominar aqui de honra. Honra advém do princípio que leva alguém a ter uma conduta íntegra, virtuosa, corajosa, honesta. A educação plena, e por isso libertária, merece seu lugar de honra.

Eis que se instaura o embate e, por assim dizer, o conflito. Ambiente de atrito. (Re)existir clama pela resiliência à resistência num dado processo de autoaprendizagem ontológica. A cibervida artista nos demonstra esta natureza pela estética da vida. Chamo pela formanda de direito Michele Maria Batista Alves. Chamo pela jovem deputada federal Tabata Claudia Amaral de Pontes, conhecida como Tabata Amaral, eleita em 2018. As estéticas identitárias do pensamento divergente dessas duas vidas artistas singularizam a poética de suas (re)existências, em que suas ciber(re)existências viralizam em nossas redes sociais. Em mais detalhes, a resistência de cada uma dessas personagens, como segue a transcrição na íntegra de suas expressões. 


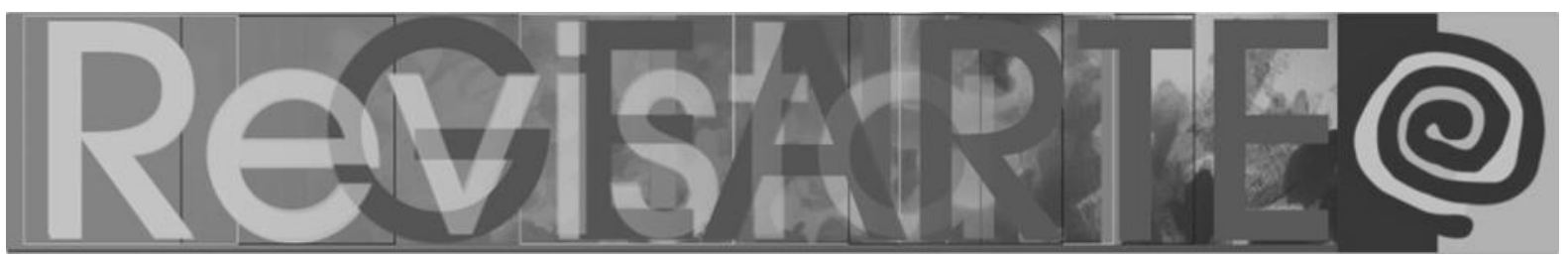

\section{Michele Maria Batista Alves}

A estudante de direito, pela PUC-SP, Michele Maria Batista Alves, 23 anos, natural de Macaúbas, cidade de 50 mil habitantes no Centro-Sul da Bahia, filha de mãe solteira, criada com a ajuda da avó, tem seu discurso de formatura proferido em 15 de fevereiro de 2018 no auditório lotado do Citibank Hall, uma enorme casa de shows da cidade de São Paulo, viralizado nas redes sociais. O discurso muito aplaudido, com a plateia em pé, Michele deu voz à resistência, contra o preconceito, nas palavras suas palavras:

Caros colegas, pai, professores, convidados, boa noite.

Depois desse discurso animado, eu venho com um discurso rápido prometo, e um discurso que fala um pouco da nossa realidade aqui na PUC. Nessa noite tão especial, na qual relembramos nossa trajetória na Pontifícia, gostaria de falar sobre resistência, palavra tão usada por nós ao longo desses 5 anos. Todavia, não quero aqui abranger toda e qualquer resistência. Quero falar de uma em específico: da resistência que uma parcela dos formandos, que infelizmente são minoria neste evento, enfrentaram durante sua trajetória acadêmica. Me dedico a resistência daqueles que cresceram sem privilégios, sem conforto e sem garantia de um futuro promissor. Daqueles que foram silenciados na universidade quando pediram voz, e que carregaram desde cedo o fardo no não pertencimento às classes dominantes. Me dedico a resistência das famílias, que a muito custo mantiveram seus filhos na universidade. A resistência dos estudantes que perderam no mínimo 3 horas diárias em transportes públicos. Hoje, trago a história de jovens sonhadores, que há cinco anos atrás iniciaram uma história de resistência nessa universidade. Trago a história de resistência da periferia, dos pretos, dos descendentes de nordestinos e dos estudantes de escola pública. Nós formandos bolsistas resistimos a PUC-SP, aos sonhos que nos foram roubados e a realidade cruel que nos foi apresentada no momento que cruzamos dos portões da Bartira e da Monte Alegre. Nós resistimos as piadas sobre pobres, as críticas sobre as esmolas que o governo nos dava, aos discursos reacionários da elite e a sua falaciosa meritocracia. Resistimos a falta de inglês fluente, de roupa social e linguajar rebuscado que o ambiente acadêmico nos exigia. Resistimos também a falta de apoio financeiro e educacional da Fundação São Paulo. Aos discursos sobre a vitimização das minorias e a suposta autonomia do indivíduo na construção do seu próprio futuro. Resistimos também aos insultos feitos a nossa classe, aos desabafos dos colegas sobre suas empregadas domésticas e seus porteiros. Mal sabiam que esses profissionais eram nossos pais. No mais, resistimos aos professores que não compreenderam nossa realidade e limitações e faziam comentários do tipo: "Por favor, não estudem direito civil por sinopse, porque até a filha da minha empregada, que faz direito na uniesquina estuda direito por sinopse". Esta frase foi dita por uma professora de direito civil no meu $3^{\circ}$ dia de aula. Após escutá-la meu coração ficou em pedaços, pois naquele dia soube que a faculdade de direito da PUC-SP não era para mim. Liguei para minha mãe, empregada doméstica, chorando e disse que ia desistir. Entretanto, após alguns minutos de choro compartilhado, ela me fez enxergar 


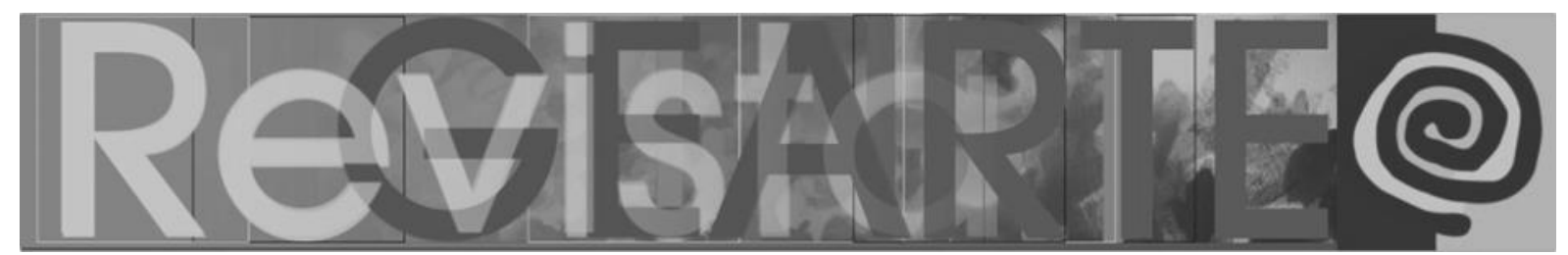

o quanto eu precisava resistir aquela situação e mostrar à PUC e a mim mesma o quanto eu era capaz de obter este diploma.

Essa história não é apenas minha, mas de todos os bolsistas formandos da PUC São Paulo. Somos os filhos e filhas do gari, da faxineira, do pedreiro, do motorista e da mãe solteira. Por isso, a eles nossos maiores inspiradores, dedicamos nossa história de resistência nessa universidade. Que nossa história, inspire outros jovens pobres a resistir. Avante companheiros! Avante, pois nossa luta está apenas começando. Por fim, como nunca é tarde para dizer: Fora Temer. Muito obrigado. (<https://www.youtube.com/wat ch?v=lbU5wmWOSR4> Acesso em: 05 out. 2018.)

\section{Tabata Claudia Amaral de Pontes}

\section{A jovem deputada federal Tabata Claudia Amaral de Pontes, conhecida como}

Tabata Amaral, que se formou em Ciência Política e Astrofísica em Harvard nos Estados Unidos, foi eleita em 2018 para lutar pela educação. Abaixo a transcrição de seu $1^{\circ}$ discurso na Câmara "A Joia de Ciro Gomes", que ocorreu em 14/02/2019:

Boa a tarde a todos e a todas colegas. Essa é minha 1a legislatura, então me parece apropriado uma breve apresentação: meu nome é Tábata Amaral, fui eleita pelo PDT em São Paulo porque 264.450 pessoas acreditaram que a política também era para gente - para as mulheres, para os jovens, para os periféricos, para aqueles que nunca tinham tido contato com esse parlamento. É muita responsabilidade ser eleita com 25 anos, mas também é uma grande oportunidade de pela $1 \underline{\underline{a}}$ vez poder realmente atuar sobre aquelas pautas que tanto me incomodaram e que tanto me movem.

Eu venho da periferia de São Paulo, com muito orgulho sou filha de cobrador de ônibus, sou filha de bordadeira e diarista e eu cheguei aqui porque uma professora com as olimpíadas de matemática de escola pública acreditou que eu também poderia estudar, porque alguns professores pagaram meu almoço, pagaram as minhas roupas, porque algumas pessoas me disseram que eu também poderia fazer faculdade mesmo que meus pais não tenham terminado o ensino médio. $E$ eu estou aqui porque com a ajuda de todas essas pessoas que foram me ensinando que também poderia sonhar, eu pude chegar a Harvard nos Estados Unidos com uma bolsa e estudar ciências Políticas e Astrofísica, coisa que meus pais nem tinham ouvido falar.

E eu chego aqui porque eu não só vivi tudo que a educação pode fazer com agente, todo o potencial que ela tem de transformar, mas também porque eu vivi o outro lado da desigualdade: eu perdi meu para as drogas, eu perdi amigos, vizinhos para a violência e para o crime. Eu me tornei uma ativista não porque parecia interessante. Eu fui feito uma ativista porque eu via importância da educação, mas eu também vi a falta que ela faz principalmente nas periferias.

Esse é o meu $11^{\circ}$ mandato, e eu cheguei aqui porque eu vi que a educação não muda se a política e os políticos não mudarem, mas mesmo que seja o meu $1^{\circ}$ mandato, eu trabalho com educação há 9 anos. Já fui professora, trabalhei em secretarias de educação, trabalhei como pesquisadora, ativista e eu fui vendo com esse trabalho, principalmente conhecendo o Sobral no Ceará, que a educação pública brasileira pode ser sim, de muita qualidade para todos. Só que esse trabalho me mostrou que o que realmente vira o 


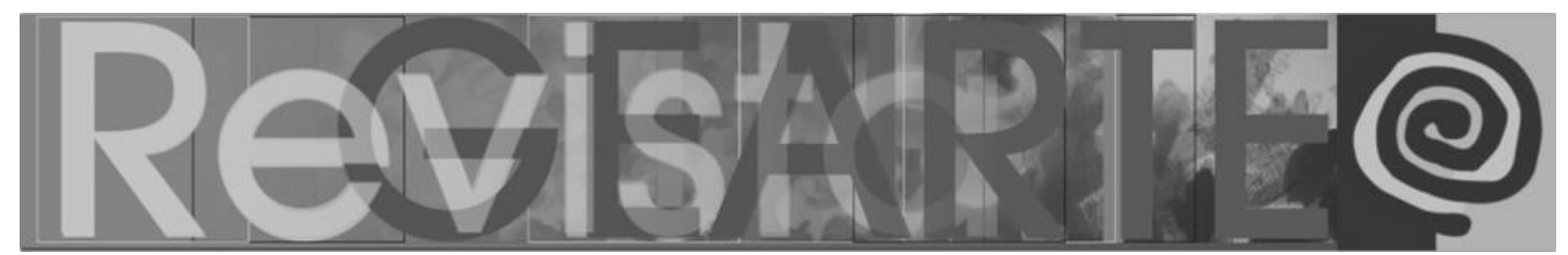

ponteiro, o que realmente importa na educação, não é o que viraliza nas redes, não são os assuntos mais polêmicos. A gente tem que falar de alfabetização ainda, a gente tem que falar de formação, de carreira dos professores ainda, a gente tem que falar de tantas pautas que parece um pouco "clichê" e repetição, só que a gente não resolveu nenhuma delas, ainda.

Agente tem que falar de uma escola em que os jovens tenham alguma chance no vestibular, no mercado de trabalho, onde eles aprendam a sonhar, e não tenham os seus sonhos destruídos, e a gente tem que falar do Fundeb, que é Fundo Nacional de Desenvolvimento da Educação Básica, um assunto muito complexo, que de novo não viraliza, mas de novo de grande importância. O Fundeb vence em um ano e a gente tem uma chance única de não só colocá-lo na constituição, de não só ampliá-lo, torna-lo mais redistributivo, mas de aproveitar essa chance para espalhar Brasil a fora boas práticas de educação. De cada 4 municípios no Brasil, 3 deles o diretor ainda é escolhido pelo vereador, sem nenhum critério. A gente tem que condicionar uma parte do Fundeb para quem treina seus professores com seriedade, para quem de fato acaba com indicação política, para quem de fato consegue melhorar a educação.

E eu estou aqui pessoal, porque a gente está em um país que em cada 10 alunos que terminam o ensino médio, e a gente sabe que muitos não chegam lá, só 3 aprenderam o que deveriam em português. De cada 100 que terminam, só 9 aprenderam o que deveriam em matemática. A gente está em um país em que o tamanho dos sonhos e até aonde você pode chegar depende de onde você nasceu, depende da cor da sua pele, depende do seu gênero. $E$ eu estou aqui falando com vocês hoje, porque me preocupa muito ver essa polarização. O que realmente importa não são as pautas virais ideológicas. O que realmente importa é tudo isso que eu trouxe para vocês. E me preocupa ver nesses primeiros dias de congresso, como a gente se paralisa e entre numa briga que não tem nenhuma consequência.

Então, eu peço a vocês, sabendo que sou jovem, e jovem é irrequieto e questiona. $\mathrm{E}$ eu represento isso bem, mas eu peço a vocês que por favor, entrem nessa luta com seriedade. A gente precisa mudar as práticas da política. E eu peço a vocês que entendam que sem educação não teremos 0 país que queremos: inclusivo, desenvolvido e ético. Muito obrigada temos 4 anos a frente e a gente precisa começar do jeito certo. E eu solicito presidente, que este pronunciamento seja divulgado à voz do Brasil. Muito obrigada a todos e a todas. (https://www.youtube.com/watch?v $=$ CFq1XKo2tGY. Acesso em: 28 fev. 2019)

Como desassociar os aspectos socioculturais, sobretudo os cibersocioculturais destas expressões de vida, que intensificam seus processos de ressignificação pela imersão dos acontecimentos tecnoculturais?

As estéticas socioculturais, presentes na sociedade em rede, são de suma importância para este estudo, no tocante às cibervidas artistas, porque o objetivo é a educação cibercultural crítica pelo/no acontecimento viral, por se acreditar no poder libertador da identidade. 


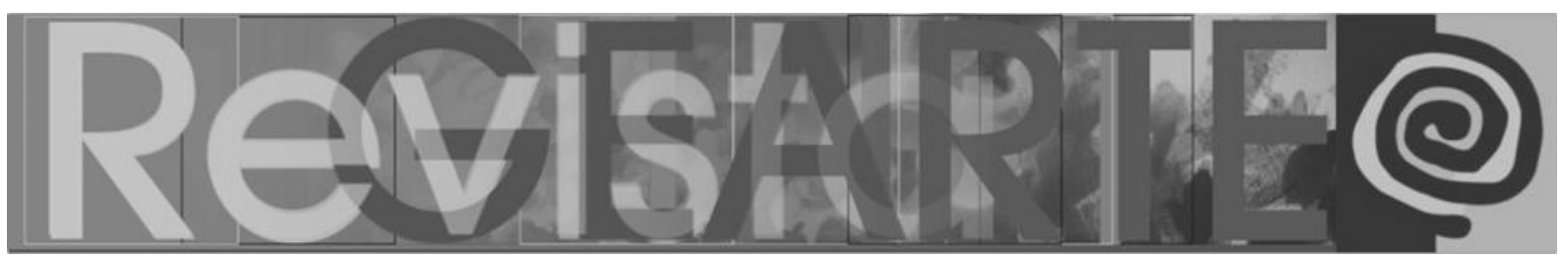

Ao se apropriar da cibervida artista, em seu caráter ciberarte/educativo pelo acontecimento viral, poder-se-á promover as potencialidades da expressão em sua gênese identitária, marcada pela singularidade da apropriação crítica do evento. Parafraseando o professor Fernando Azevedo: 0 desenvolvimento da ciberdemocratização - e por assim dizer da ciberdescolonização - da produção do pensamento que diverge dos padrões deve arte-educar em prol da resolução de problemas com imaginação ciberpoética. Eis que se instaura a necessidade de se desenvolver a capacidade indissolúvel de ciberapreciar e ciberexpressar de nossos jovens pela autogovernabilidade.

\section{Ciberapreciação, ciberexpressão: acontecimentos contextuais demarcados pela autoaprendizagem}

Uma das características, talvez a mais importante, da tecnocultura é sua capacidade de captar a maioria das expressões no âmbito de sua diversidade social/cultural/tecnológica. Seu ponto marcante, como pudemos observar antes, é o fim da separação e divisão entre as mídias audiovisuais e impressas e a oralidade, bem como o fim da separação entre cultura popular e erudita, entretenimento e informação. Por certo, a tecnocultura viabiliza a interação entre esses códigos comunicacionais num único universo digital interativo, constituindo um novo ambiente simbólico. Esse universo, ao tornar a virtualidade uma realidade expressiva, liga as manifestações em todos os seus tempos e espaços, contidas em nossa mente comunicativa, transformando a virtualidade em um sistema comunicacional e, portanto, real. É o que adverte Castells (1999, p. 354):

Finalmente, talvez a característica mais importante da multimídia seja que ela capta em seu domínio a maioria das expressões culturais em toda a sua diversidade. Seu advento é equivalente ao fim da separação e até da distinção entre mídia audiovisual e mídia impressa, cultura popular e cultura erudita, entretenimento e informação, educação e persuasão. Todas as expressões culturais, da pior à melhor, da mais elitista à mais popular, vêm juntas nesse universo digital que liga, em um supertexto histórico gigantesco, as manifestações passadas, presentes e futuras da mente comunicativa. Com isso, elas constroem um novo ambiente simbólico. Fazem da virtualidade nossa realidade. 


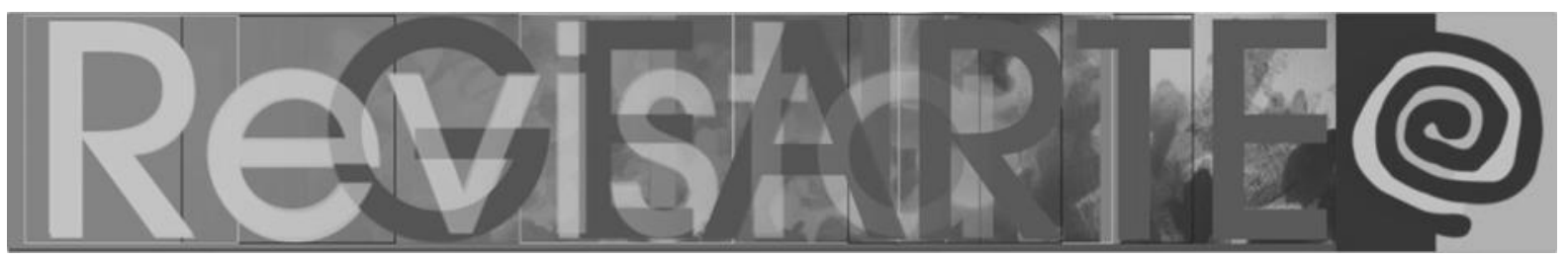

Compõem-se, então, novas formas de relações, bem como um novo estado da mente - a metalinguagem -, a qual está proporcionando a infraestrutura mental para a comunicação integrada em um tempo escolhido (real ou atrasado), constituindo, dessa forma, um novo conceito de comunicação e, portanto, de cultura da humanidade.

A vida humana, sabemos, não é somente a interação com a matéria, mas também o embate do homem com sua própria alma. Para a indústria ideológica massiva, é essencial capturar a alma humana para disseminar o consumismo em larga escala. Isto faz dela um importante veículo/instrumento utilizado no capitalismo para a ditadura de valores. Desse modo, é imperativo um processo de ensinoaprendizagem pelo acontecimento em promoção do desenvolvimento da consciência autônoma e por isso crítica da capacidade de ler e interpretar os eventos presentes no universo digital que os cerca.

Entretanto, o apoderamento tecnológico no sistema capitalista nos leva a questionar se há fábricas de felicidade onipresentes entre nós que nos induzem ao consumo acrítico, mecânico, padronizado, como uma tecnologização ubíqua de nossos sonhos capturados (mas que, na verdade, são condicionados, impostos, introjetados).

A educação uniformizada exclui as diferenças, massificando os valores e desejos humanos. Diante disso, é de extrema relevância que os governantes de nosso país, bem como os dirigentes educacionais, postulem uma política responsável e comprometida com a ressonância dos acontecimentos virais pela utilização das tecnologias da informação (TIs), com vistas aos seus impactos socioculturais.

Sabe-se, de antemão, que as propostas de democratização digital devem ser fundamentalmente educativas, porque só a educação insere a pessoa plenamente no mundo. A pessoa alfabetizada digitalmente tem de ser capaz de decodificar e interpretar o mundo que a cerca crítica e autonomamente. 


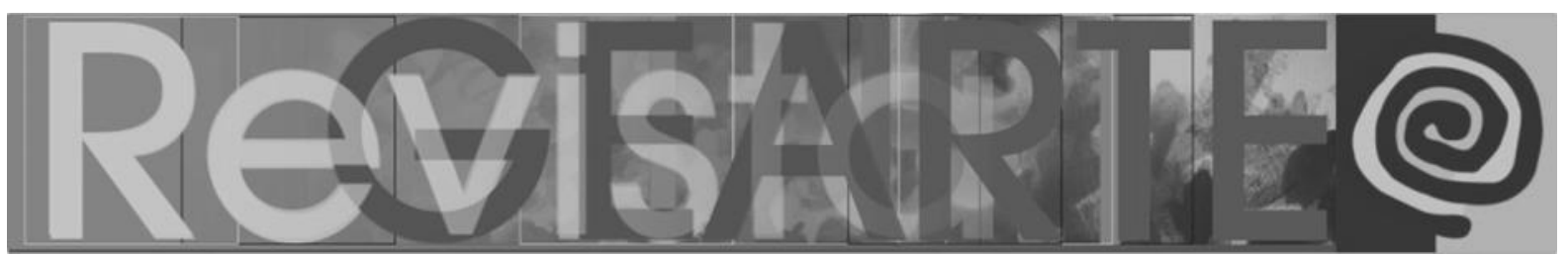

$\mathrm{Na}$ nossa labuta como educadores, artistas e professores de arte, não queremos formar pessoas em série, acríticas e com seus desejos colonizados pelo imperialismo vertical globalizante. Tenho como premissa pulsante e indócil uma ciberarte/educação pelo acontecimento viral, que promova a globalização horizontal, democrática - dialogal, multi/intercultural e por isto libertadora. Ciberapreciação, ciberexpressão, pelas suas vias, devem ser marcadas pela identidade em seu processo genuinamente de ciberacontecimento.

Na contramão do império da ditadura globalizante, hegemônica, em que o capitalismo global, não centralizado, mas com poder vertical, manipulador, acentua o analfabetismo e a homogeneização do pensamento humano, o ciberespaço deve ser um sistema marcado pela identidade plural, em que as partes formam um todo não homogeneizado, multicultural, multidialogal, multidisciplinar, interdisciplinar e assimétrico. Há de se estabelecer uma globalização (presente nas redes vivas como a internet) ecológica/ética, para dinamizar a identidade pessoal pelo (re)conhecimento das diferenças por meio de uma interatividade crítico-autônoma. A cibervida artista torna-se essencial à arte e seu ensino ao buscar promover o (re)conhecimento identitário da estética de vida bem como o desenvolvimento da capacidade da ciberexpressão-ciberapreciação crítica de nossos alunos e alunas.

A contemporaneidade é demarcada pela era Ciber, um universo mediado pelo acontecimento líquido. Pelo contexto da navegação. Na contramão do "homem lento", personagem criada por Milton Santos (1994, 1996), e em direção ao paradigma da modernidade líquida do sociólogo Zygmunt Bauman (2000), o sociólogo inglês John Urry (2005) nos adverte que o contexto não é, portanto, apenas relevante, mas elemento estruturador de um sistema concomitantemente mutante, como diz Bohm: "A dança é que é fundamental, e não os dançarinos" (apud Urry, 2005, p. 238, tradução nossa.)

Apreciação e expressão têm como essência a capacidade de atribuição de significado. E em seu valor autônomo, o significado tem caráter identitário. A identidade do pensamento divergente se constrói pela elaboração e solução de 


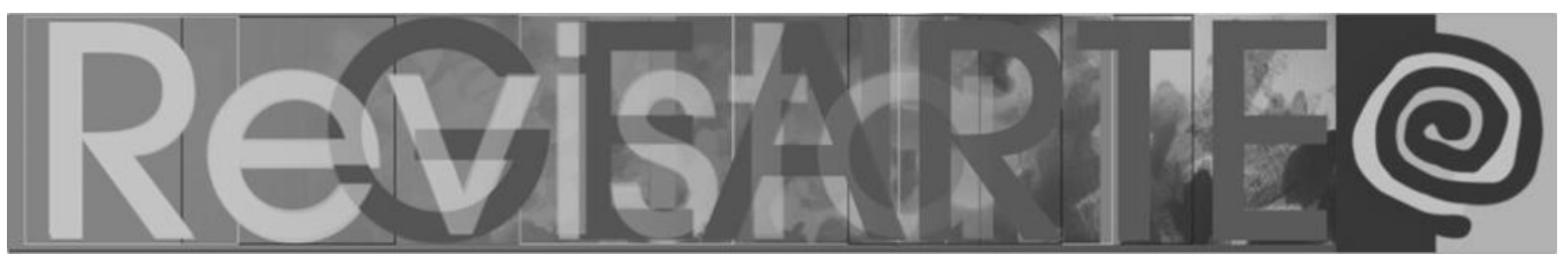

problemas, em que há de haver a capacidade estética de interpretação poética em um determinado contexto. A percepção cognitiva se manifesta na interseção da solução de um problema em um determinado contexto. O contexto procede da interpretação inter-relacional de circunstâncias de fatos e/ou situações no encadeamento do discurso à elaboração do significado para a manifestação humana. A estética advém da interpretação poética de um determinado contexto. Logo, a natureza da estética do pensamento divergente perfaz nossas manifestações sígnicas de caráter identitário, autônomo e descolonizador advindos de acontecimentos contextuais.

O ciberuniverso, pela sua natureza estrutural sistêmica e, portanto, complexa, subverte a relação entre tempo e espaço. Por isso, é um sistema não linear, cuja fluidez líquida transcende e se contrapõe à concepção da verdade única, inquestionável de sistemas lineares presentes na física clássica. Sendo assim, o contexto é elemento fundamental para determinar a rota de significados e valores que construiremos em uma caminhada virtualmente empírica em nossas cibervidas.

Vale ressaltar que a era Ciberé mediada pela era Inter, em razão de seus aspectos plurais que se amalgamam com caráter democrático, horizontal. A internet, pela sua gênese no hipertexto, seu caráter expressivo e/ou apreciativo mediante a vivência de rotas navegadas, pode promover múltiplos caminhos capazes de cartografar diferentes e autônomas narrativas de acordo com rotas escolhidas. Tais rotas, vale dizer, são propulsoras de acontecimentos contextuais, de processos de autoaprendizagem. Descobertas significativas necessitam de autonomias no/pelo percurso.

A promoção da autonomia pela cultura digital se constitui, em outros termos, em uma rede de informações que, por meio de rotas escolhidas, poderá levar a pessoa a diferentes formulações. Para cada caminho traçado, poderá haver resultados diferentes. Verdades que eram absolutas (e, de certo modo, universais) agora são relativizadas, de acordo com o contexto que vai se amalgamando no percurso, instituindo o contexto como elemento significante e significativo nesse meio: o contexto como elemento epistemológico do acontecimento (evento). 


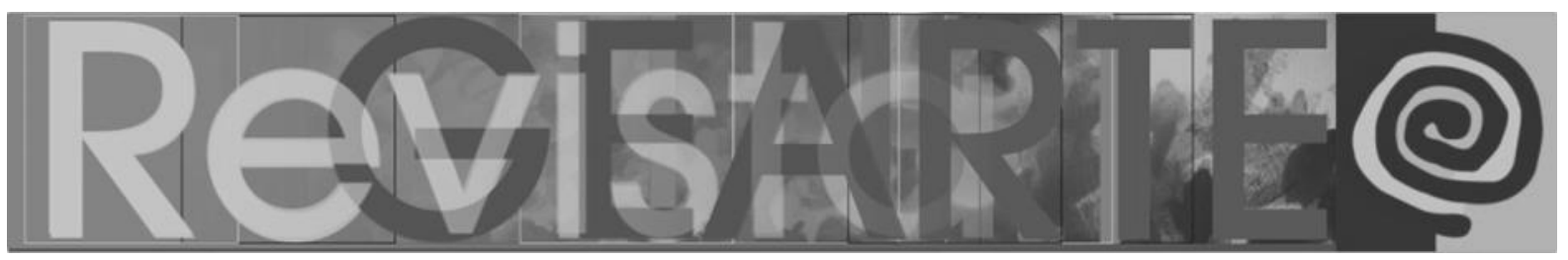

\section{Cirberexpressão pelo acontecimento viral}

Nenhuma mudança se funda no nada, na negação da história ou da realidade ou das suas aparências, por mais efêmeras que se apresentem aos nossos olhos, quando eles veem para fora. Todas as utopias se reportam ao que existe e tudo o que existe aspira ao que não existe. O que não existe precisa do que existe - como se fosse a sua face mais oculta.

(Ademar Ferreira dos Santos, apud ALVES, 2012, p. 9).

O que seria das invenções, dos processos culturais se não houvesse utopia?

Circunscreve-se a estética do universo de ações cirberpedagógicas pelo acontecimento viral como gesto de (re)existência do ensino da ciberarte libertária para que a pessoa seja capaz de se expressar com autogovernança.

Esse processo humano/crítico/inventivo deve atender à força motriz de seus desejos expressivos, que podem estar alicerçados na generosidade, solidariedade. A ciberexpressão pode e deve ser uma instância ciberarte/educativa que promova a descoberta do que há de mais humano no ser humano. A arte, por meio do movimento de arte para a reconstrução social, tem apresentado sua relevância para a vida das pessoas.

O ensino da arte não pode ser negligenciado. A expressão humana é uma necessidade inerente à pessoa. Sem a capacidade plena de expressar-se, compreendo que um homem e/ou uma mulher são deficientes. O escritor e professor português Ademar Ferreira dos Santos $(\underline{1952-2010})^{6}$, no prefácio ao livro de Rubem Alves intitulado $A$ escola com que sempre sonhei sem imaginar que pudesse existir nos promove uma experiência empírica ao se submergir na narrativa do exercício educativo crítico pelos passos da curiosidade, da aventura, do encorajamento, da autogovernança e assim impulsiona à questão de como proteger nossos jovens alunos e alunas das incursões obrigatórias que sufocam o prazer da descoberta?

O universo Ciber, como bem sabemos, não é silencioso. É ambiente de diversidade.

6 Foi presidente da Direção da Escola da Ponte em Vila das Aves, Portugal, uma escola com um modelo internacional em práticas pedagógicas inovadoras. 


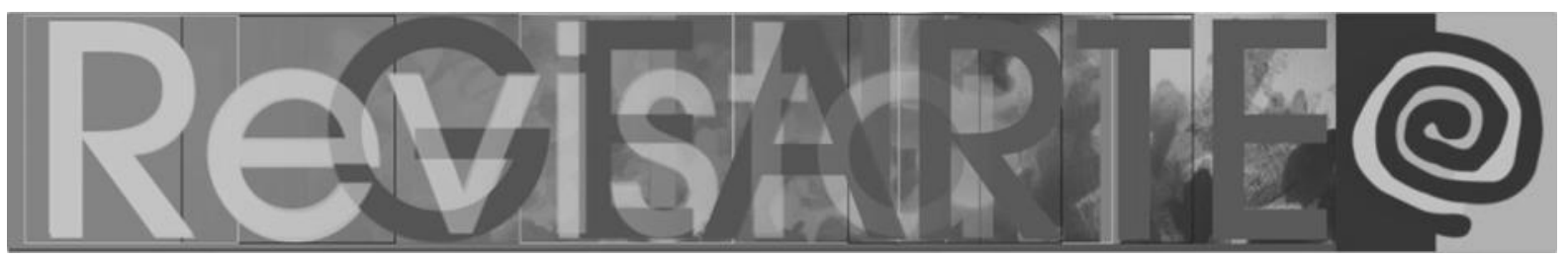

A ciberarte/educação crítica não pode ser silenciosa. Insere-se na prática pelo exercício pedagógico sábio, por isso libertário, entre palavras e gestos (intimamente sábios) expressos pelo acontecimento, para ajudar serenamente a ler e a escrever a própria vida.

No âmbito da autogestão dos riscos discentes no processo de ensinoaprendizagem delineado pelo acontecimento em prol da autonomia, transgridem-se padrões tecnoeducacionais que muitas vezes acabam castrando o processo inventivo de nossos alunos e alunas por intermédio de ações $C t r l+A l t+D e l$ que formatam valores pessoais e ignoram o tempo de cada um. Nesse paradigma se cala a percepção que dialoga com o universo interno e externo da pessoa, roubando-Ihe a capacidade de sonhar, de imaginar, de criar. De expressar, pois é "esse mundo interior, só captável pelo olhar para dentro, que dá a expressão à nossa identidade e singulariza o nosso destino", quando "nos apercebemos de que há um imenso mundo para além ou aquém do mundo que espreitamos fora de nós", diz o professor Ademar Ferreira dos Santos (2012, p. 10).

Talvez seja nesta instância que um coração, ainda que se pareça sem vida, congelado, enjaulado poder-se-á (re)criar-se à vida, num dado processo íntimo de descolonização da alma... Pode-se trazer a certeza, nesta instância, o coração - que como flor, se desabrocha num processo expressivamente sígnico, íntimo, que se consagra potentemente com a viralização da sua identidade. Dada sua ciberexpressão identitária viral crítica, se enaltece e fortalece outras vozes, aqui compreendidas como promoção do desenvolvimento ontológico de ciber autoaprendizagem. Um processo expressivo-cibereducativo em cascata. Importante proposição pedagógica para a cibercontemporaneidade, que não pode ser ignorado, negado, negligenciado.

Os sistemas complexos, em oposição aos muitos sistemas lineares nãocomplexos, são potencialmente instáveis, nada é fixo para sempre e existe "a possibilidade de um padrão de ações ocorrer, de pôr a chave na fechadura e fazer um momento decisivo de mudança acontecer" (ABBOTT, 2001, p. 257). Eis que se apresenta a possibilidade concreta e não utópica de se viabilizarem ações 


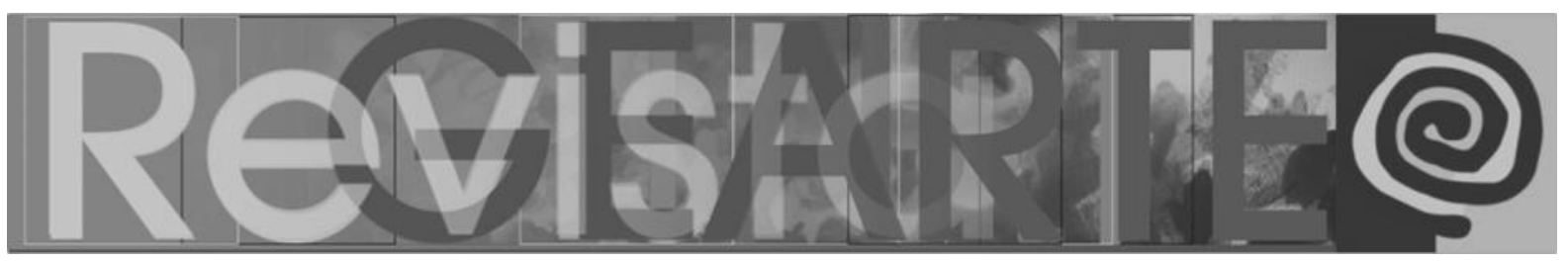

educacionais no processo de ensino/aprendizagem em que se poderão desenvolver níveis os consciência humana, já descritos por Paulo Freire da intransitividade à transitividade crítica, podendo-se estabelecer, assim, uma educação libertadora.

Assim, as indústrias culturais que insistem na produção do pensamento massivo acrítico podem se surpreender com uma indústria educacional edificadora do pensamento crítico/autônomo - por que não? O que pode impedir, num simples movimento de introdução de chave na fechadura, acionarmos movimentos educacionais em prol da formação do pensamento autônomo da pessoa?

Os processos pedagógicos demarcados pela coragem de assumir riscos não são suicidas, no tocante ao intento pedagógico crítico, que viabiliza o desenvolvimento da capacidade da consciência autogovernativa de mensurar e assim refinar a percepção factível aos ricos da jornada ante ao passo que se instaura à caminhada.

\section{Referências}

ABBAGNANO, Nicola. Dicionário de filosofia. São Paulo: Martins Fontes, 2000.

ABBOTT, A. Time Matters. Chicago: University of Chicago Press, 2001.

ALVES, Rubens. A escola com que sempre sonhei sem imaginar que pudesse existir. Campinas, SP: Papirus, 2012.

ALVES, Michele Maria Batista. Discurso de formatura da PUC-SP proferido no auditório lotado do Citibank Hall em 15 de fevereiro de 2018. Disponível em: <https://www.youtube.com/ watch?v=lbU5wmWOSR4> Acesso em: 05 out. 2018.

ATKINSON, Dennis. Pedagogy of the Event. Goldsmiths: University of London, 2014. Disponível em: <http://www.kettlesyard.co.uk/wp-content/uploads/2014/12/onn_atkinson.pdf>. Acesso em: 14 maio 2018.

AZEVEDO, Fernando A. G. de. Viver a vida como uma obra de arte: por uma arte/educação que diz sim às diferenças. In: LIMA, Sidney P. F. de (Org.). Arte e pedagogia: a margem faz parte do rio. São Paulo: Porto de Ideias, 2017. p. 121-140.

BARBOSA, Ana Mae. Tópicos utópicos. Belo Horizonte: C/Arte, 1998.

BARBOSA, Ana Mae. Mediação cultural é social. In: BARBOSA, Ana Mae; COUTINHO, Rejane (Org.). Arte/Educação como mediação cultural e social. São Paulo: Ed. Unesp, 2009.

BARBOSA, Ana Mae. Ana Mae informa: Primeiro Congresso Internacional de Educação Artística e Cultura Visual "Hacia uma Educación Inclusiva e Interrelacional". Disponível em: <http://www3.eca. usp.br/sites/default/files/form/biblioteca/acervo/producaoacademica/002735784.pdf> Acesso em: 10 maio 2018.

BADIOU, Alain. Ethic: an essay on the understanding of evil. Translated and introduced by Peter Hallward. London: Verso, 2001.

BAUMAN, Zygmunt. Modernidade líquida. Rio de Janeiro: Zahar, 2000. 


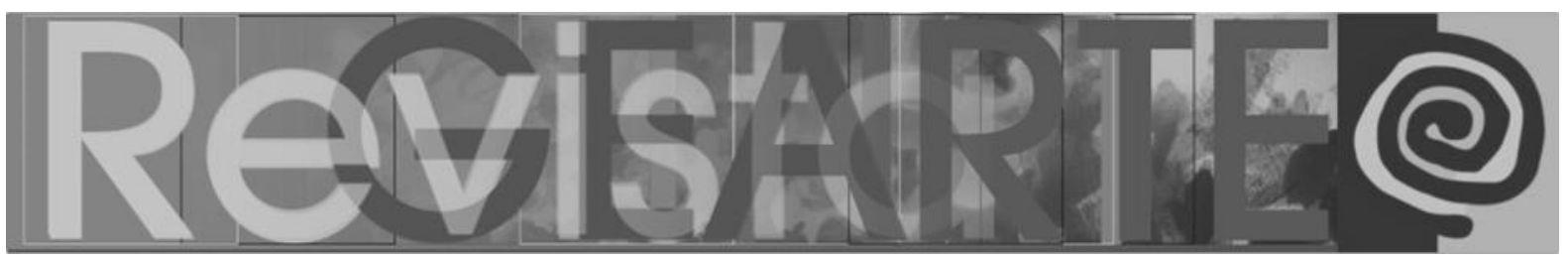

CASTELLS, Manuel. A sociedade em rede: a era da informatização: economia, sociedade e cultura. 2. ed. v. 1. São Paulo: Paz e Terra, 1999.

DEWEY, John. Arte como experiência. São Paulo: Martins Fontes, 2010.

PONTES, Tabata Claudia Amaral de. $1^{\circ}$ Discurso Na Câmara - "A Joia de Ciro Gomes" em 14/02/2019. Disponível em: <https://www.youtube.com/watch?v=CFq1XKo2tGY>. Acesso em: 28 fev. 2019.

FREIRE, Paulo. Pedagogia do oprimido. 29. ed. Rio de Janeiro: Paz e Terra, 1987.

FREIRE, Paulo. A importância do ato de ler: em três artigos que se completam. 44. ed. São Paulo: Cortez, 2003.

FREIRE, Paulo. Educação como prática da liberdade. 28. ed. Rio de Janeiro: Paz e Terra, 2005.

LECERCLE, Jean-Jacques. Cantor, Lacan, Mao, Beckett, memê combat: the philosophy of Alain Badiou. Radical Philosophy, v. 93, p. 6-13, 1999.

SANTOS, Milton. A natureza do espaço: técnica e tempo, razão e emoção. São Paulo: Hucitec, 1996.

SANTOS, Milton. Técnica, espaço e tempo: globalização e meio técnico-científico informacional. São Paulo: Hucitec, 1994.

SWIFT, John; STEERS, John. A manifesto for art in schools. Directions: The International Journal of Art and Design Education, v. 18, n. 1, p. 7-14, 1999.

URRY, John. The complexities of the global. Theory, Culture \& Society, London, Thousand Oaks and New Delhi, v. 22, n. 5, p. 1-14, 2005.

RATIER, Rodrigo. Quem é a aluna bolsista cujo discurso de formatura viralizou na rede. Geledés Instituto da Mulher Negra, 22 fev. 2018. Disponível em: <https://www.geledes.org.br/quem-e-alunabolsista-cujo-discurso-de-formatura-viralizou-na-rede/> Acesso em: 26 abr. 2018.

SANTOS, Ademar Ferreira do. Prefácio. In: ALVES, Rubem. A escola com que sempre sonhei sem imaginar que pudesse existir. Campinas, SP: Papirus, 2012. Edição digital.

SILVA, Tomaz Tadeu da. Documentos de identidade: uma introdução às teorias do currículo. Belo Horizonte: Autêntica, 2007.

\section{Fernanda Pereira da Cunha}

Possui graduação em Educação Artística - Licenciatura Plena pela Fundação Armando Álvares Penteado, mestrado em Artes pela Universidade de São Paulo e doutorado em Artes pela Universidade de São Paulo. Atualmente é Professora Associada da Escola de Música e Artes Cênicas da Universidade Federal de Goiás (EMAC/UFG). Tem experiência na área de Artes, atuando principalmente nos temas: Intermídia, Cultura Digital, e-Arte/Educação. Foi vice-coordenadora do Programa de Pós-Graduação Stricto Sensu (mestrado e doutorado) Interdisciplinar em Performances Culturais (2015-2016). É coordenadora do Curso de Especialização em Arte/Educação Intermidiática (EMAC/UFG).

E-mail: fernanda.pcunha@hotmail.com

Currículo: http://lattes.cnpq.br/8739909013018488

Recebido em 3 de março de 2019 Aceito em 21 de maio de 2019 